OPEN ACCESS

Edited by: Raffaella Balestrini,

Consiglio Nazionale delle Ricerche

(CNR), Italy

Reviewed by:

Eustachio Tarasco,

Università degli Studi di Bari Aldo

Moro, Italy

Marco Mucciarelli,

Università degli Studi di Torino, Italy

*Correspondence:

Liande Wang

liande_wang@126.com

Specialty section:

This article was submitted to Fungi and Their Interactions,

a section of the journal

Frontiers in Microbiology

Received: 10 November 2017

Accepted: 09 March 2018

Published: 23 March 2018

Citation:

Bamisile BS, Dash CK, Akutse KS, Keppanan R and Wang L (2018)

Fungal Endophytes: Beyond Herbivore Management.

Front. Microbiol. 9:544.

doi: 10.3389/fmicb.2018.00544

\section{Fungal Endophytes: Beyond Herbivore Management}

\author{
Bamisope S. Bamisile 1,2,3, Chandra K. Dash ${ }^{1,2,3,4}$, Komivi S. Akutse ${ }^{5}$, \\ Ravindran Keppanan ${ }^{1,2,3}$ and Liande Wang ${ }^{1,2,3 *}$
}

'State Key Laboratory of Ecological Pest Control for Fujian and Taiwan Crops, Fujian Agriculture and Forestry University, Fuzhou, China, ${ }^{2}$ College of Plant Protection, Fujian Agriculture and Forestry University, Fuzhou, China, ${ }^{3}$ Key Laboratory of Integrated Pest Management for Fujian and Taiwan Crops, Ministry of Agriculture, Fujian Agriculture and Forestry University, Fuzhou, China, ${ }^{4}$ Department of Entomology, Faculty of Agriculture, Sylhet Agricultural University, Sylhet, Bangladesh,

${ }^{5}$ International Centre of Insect Physiology and Ecology, Nairobi, Kenya

The incorporation of entomopathogenic fungi as biocontrol agents into Integrated Pest Management (IPM) programs without doubt, has been highly effective. The ability of these fungal pathogens such as Beauveria bassiana and Metarhizium anisopliae to exist as endophytes in plants and protect their colonized host plants against the primary herbivore pests has widely been reported. Aside this sole role of pest management that has been traditionally ascribed to fungal endophytes, recent findings provided evidence of other possible functions as plant yield promoter, soil nutrient distributor, abiotic stress and drought tolerance enhancer in plants. However, reports on these additional important effects of fungal endophytes on the colonized plants remain scanty. In this review, we discussed the various beneficial effects of endophytic fungi on the host plants and their primary herbivore pests; as well as some negative effects that are relatively unknown. We also highlighted the prospects of our findings in further increasing the acceptance of fungal endophytes as an integral part of pest management programs for optimized crop production.

Keywords: fungal endophytes, biological control, entomopathogenic fungi, host plants protection, integrated pest management

\section{INTRODUCTION}

Endophytes are ubiquitous, forming associations with a diverse group of organisms throughout the plant kingdom and provide indirect defense for plants against herbivores (Hartley and Gange, 2009). Endophytes can exist in a host plant in the form of mutualistic root endophytes or plantassociated endophytes (Vega, 2008). They are plant-associated microorganisms that colonize and live part of their life cycle within a plant without causing harm or disease (such as lesions, retardation in growth, discoloration or chlorosis, etc.) to their host (Hardoim et al., 2015; Puri et al., 2016).

The tissues and organs of the host plants such as leaves, branches, stems, fruits, flowers, and roots are often colonized by fungal endophytes without showing visible symptoms (Saikkonen et al., 2006). Some fungal endophytes can also act as insect pathogenic agents by infecting lepidopterous larvae, aphids, thrips, and other cosmopolitan insects, which are of great concern in agriculture worldwide. They are known to infect specific hosts and pose little or no risk to non-target organisms or beneficial insects (Akutse et al., 2014).

There are various reports of possible artificial inoculation of plants with fungal entomopathogens to establish as plant endophytes artificially (Quesada-Moraga et al., 2009; 
Tefera and Vidal, 2009; Gurulingappa et al., 2010; Brownbridge et al., 2012; Parsa et al., 2013; Qayyum et al., 2015; Greenfield et al., 2016). Some previous reviews were focused on the role of endophytic fungi in plant herbivore management (Clay, 1989; Carroll, 1991, 1995; Breen, 1994; Saikkonen et al., 1998; Azevedo et al., 2000; Vega, 2008). Herein, we indicated that fungal endophytes such as Beauveria bassiana (Balsamo) Vuillemin (Ascomycota: Hypocreales) not only protect host plants from arthropod pests (Arnold and Lewis, 2005; Reddy et al., 2009; Akello and Sikora, 2012; Biswas et al., 2013), but also protect its hosts from diseases (Ownley et al., 2004, 2008b) and plant parasitic nematodes (Elmi et al., 2000; Sikora et al., 2007; Sikora et al., 2008), as well as enhance plant growth (Jaber and Enkerli, 2016; Jaber and Araj, 2017). Our review further summarized other effects of fungal endophytes on their host plants and primary pests. Furthermore, we highlighted the major sub-classes in which fungal endophytes can be classified based on criteria such as: their mode of reproduction, the source of nutrition, mode of transmission, symptoms expression in the hosts, the colonized plant parts, and their general morphology. We are of the opinion that the general knowledge of these findings would help to improve the application and overall adoption of fungal endophytes for pests and diseases management programs.

\section{FUNGAL ENDOPHYTES}

Fungal endophytes have been reported as naturally occurring in several host plants (Saikkonen et al., 1998; Suryanarayanan, 2013). A single plant part (leaf, stem, or root) can contain different endophyte species (Cherry et al., 1999; Vega et al., 2008; Fürnkranz et al., 2012). Higher vascular plants have been found hosting endophytic fungi in a symbiotic plant-fungus interaction (Arnold and Lewis, 2005). The interaction is termed symbiotic, as endophytic fungi, in exchange for the nutrients derived from the host plants, provide benefits to their hosts. These fungal endophytes existing symbiotically within the colonized host plants are utilized as an indirect defense against herbivores (Kim et al., 2007, 2008; Powell et al., 2009; Quesada-Moraga et al., 2009).

Many fungi traditionally known as insect pathogens such as Beauveria bassiana, Clonostachys rosea, Isaria farinosa, and Acremonium sp. (now known as Neotyphodium) have been isolated as naturally occurring endophytes from asymptomatic plant tissues (Bills and Polishook, 1991; Cherry et al., 1999; Pimentel et al., 2006; Vega et al., 2008; Orole and Adejumo, 2009). In addition to the aforementioned, some many more endophytic entomopathogenic fungi were reported to have been re-isolated from colonized host plants after artificial inoculation. These include Metarhizium anisopliae (Fuller-Schaefer et al., 2005; Akello and Sikora, 2012; Greenfield et al., 2016); B. bassiana (Bing and Lewis, 1991, 1992; Wagner and Lewis, 2000; Parsa et al., 2013; Russo et al., 2015); Fusarium oxysporum, Hypocrea lixii, Gibberella moniliformis, and Trichoderma asperellum (Akello, 2012; Akello and Sikora, 2012; Akutse et al., 2013). According to the authors, artificially inoculated entomopathogenic fungi were successfully colonized at various degrees of endophytic colonization.

So far, using various artificial inoculation methods, successful colonization of several endophytic entomopathogenic fungi have been reported in wheat (Triticum aestivum) (Gurulingappa et al., 2010; Russo et al., 2015), common bean (Phaseolus vulgaris) (Akutse et al., 2013; Parsa et al., 2013, 2016), corn (Zea mays) (Bing and Lewis, 1991, 1993; Wagner and Lewis, 2000), tomato (Lycopersicon esculentum) (Ownley et al., 2008b; Qayyum et al., 2015), soybeans (Glycine max) (Russo et al., 2015), coffee (Coffea spp.) (Posada et al., 2007), opium poppy (Papaver somniferum) (Quesada-Moraga et al., 2006, 2009) cassava (Manihot esculenta) (Greenfield et al., 2016), sorghum (Sorghum bicolor) (Tefera and Vidal, 2009), cotton (Gossypium hirsutum) (Ownley et al., 2008b; Lopez et al., 2014; Lopez and Sword, 2015), and in some other economically important crops.

Generally, fungal endophytes are known to be beneficial to crop plants, while only few species can be pathogenic by causing diseases to the host after an incubation or latency period. Some species are neutral without offering benefit or posing harm to their hosts (Sikora et al., 2007, 2008). Petrini (1991) opined that some endophytic fungal species may exist as latent or inactive pathogens, but become active and reproduce under certain environmental conditions or when their host plants are stressed or grow old. This was supported by the findings of Alvarez-Loayza et al. (2011). Agrios (1988) on the other hand, described latent infections as the condition in which the host is infected without showing any symptoms. The pathogen is inactive or in latent state until symptoms are induced as a result of environmental changes, nutritional conditions of the host plant or the stage of maturity of the pathogen or the host.

There are speculations that, many thousands of endophytes useful to mankind are currently exiting but still unexplored due to limited research attention in this related field. However, with environmental contamination, deforestation, habitat fragmentation and biodiversity losses, many of these endophytes might be permanently lost before their value is explored (Kandalepas et al., 2015). There is, therefore, need to explore these biological agents reservoir not only for the management of arthropod pests and diseases, but also to elaborate on their diversity and other functions under different agro-ecological zones.

\section{CLASSIFICATION OF FUNGAL ENDOPHYTES}

Endophytes are diverse in taxonomy, but only few species have been isolated, identified and characterized to date (Hawksworth, 2001). Fungal endophytes can be classified broadly into ecological categories or otherwise, in terms of their diversity or functional roles. Based on these categories, they have been grouped into two major groups as clavicipitaceous and non-clavicipitaceous fungal endophytes. Clavicipitaceous fungal endophytes are mostly common in grasses, while the non-clavicipitaceous are predominant with vascular and non-vascular plant species (Rodriguez et al., 2009). 
However, various authors have indicated the need to further classify these fungal endophytes to sub-classes based on different criteria such as: the host range, the mode of reproduction, the part of plant colonized, the mode of transmission, source of nutrition, and ability to express symptoms in the host plant (see Varma et al., 1999; Brem and Leuchtmann, 2001; Saikkonen et al., 2002; Rodriguez et al., 2009; Purahong and Hyde, 2011).

Fungal endophytes are classified based on the mode of reproduction as: sexual or asexual (Brem and Leuchtmann, 2001). For instance, the Epichloë endophytes have been divided into the genera Epichloë and Neotyphodium (formally Acremonium) that reproduces sexually and asexually respectively (Moon et al., 1999; Leuchtmann et al., 2000; Schardl and Craven, 2003).

They can as well be classified based on the mode of transmission in the host as: vertically-transmitted and horizontally-transmitted endophytes (Saikkonen et al., 2002). Vertically-transmitted endophytes are transferred directly from the host plants (parents) to their progenies (Saikkonen et al., 2002). True endophytes (such as the species belonging to the genus Neotyphodium) are mostly vertically transmitted through seeds from one plant to another (Hartley and Gange, 2009). When transmission is vertical through the host seeds, they are referred to as seed-transmitted endophytes (Dongyi and Kelemu, 2004; Bennett et al., 2008). Most Epichloë endophytes are seedtransmitted endophytes (Schardl et al., 2013). In addition, the paper of Quesada-Moraga et al. (2014) also reported vertical transmission of $B$. bassiana through seeds in opium poppy plants inoculated artificially via seed soaking.

On the other hand, horizontally-transmitted endophytes are transferred between different individuals in a given population. This mode of transmission is common with fungal endophytes that infect plants via airborne spores (Hartley and Gange, 2009). In this case, endophytes are usually multiplied via vegetative propagules, or transmission by spores in the case of spore-transmitted endophytes (Faeth and Fagan, 2002). Most woody and herbaceous plants harbor different species of unspecialized endophytic fungi. These fungal species which generally exhibit weak pathogenicity against insect herbivores are mostly transmitted horizontally (Higgins et al., 2007; Sieber, 2007).

Another classification is based on the source of nutrition, that is, whether nutrients are derived by the fungus from living or dead matter. Based on this, endophytes can be classified as necrotrophs, or as biotrophs. Biotrophic fungi are the types that develop and obtain nutrients within the tissue of a living host, while, necrotrophic fungi are the species that mortify the host cells in order to grow on the dead tissues (Kemen and Jones, 2012; Delaye et al., 2013). All endophytes are heterotrophs, unlike green plants that utilize $\mathrm{CO}_{2}$ directly for photosynthesis, they obtain carbon from the plants in the form of organic compounds (Pace, 1997). These fungi-plant interactions occur when endophytic fungi obtain their carbon supply from their hosts, and in exchange for the energy resources they derived from the host plants, provide benefits to the plant (Lekberg and Koide, 2005; Behie et al., 2012; Behie and Bidochka, 2014). However, as a result of periodic evolutionary and ecological changes, there is possibility of some fungal endophytes switching between the two lifestyles. That is, from biotrophic to necrotrophic lifestyle (Promputtha et al., 2007; Purahong and Hyde, 2011; Delaye et al., 2013). For instance, Leptosphaeria maculans occurring asymptomatic in healthy Arabidopsis thaliana plants became a necrotrophic pathogen when the plant was stressed (Junker et al., 2012).

Based on the expression of infection, endophytes are classified as symptomatic (expressing symptoms) and asymptomatic (symptomless) (Pinto et al., 2000). A good number of endophytic fungi infect above ground internal plant tissues without showing symptoms. Great attention is focused on these species of endophytes because they are ubiquitous and have vast diversity and many roles (Saikkonen et al., 2006; Arnold and Lutzoni, 2007). For instance, Fusarium spp. was identified as asymptomatic as it was confirmed to express no symptoms in cord roots of banana cultivar (Pisang Awak - Musa ABB) (Niere, 2001; Sikora et al., 2008). Although in some rare cases, symptomatic endophytes can be categorized as asymptomatic when the host plant is resistant to the fungi. However, as earlier stated, a change in environmental conditions could cause a sudden switch in the behavior of asymptomatic endophytic fungi. A clear example is the case of fungal species that were isolated as symptomless endophytes, yet, became pathogenic under changed environmental conditions (Delaye et al., 2013). To this end, we can reach a conclusion that, the age of the host plant harboring the fungus and the environmental conditions have a larger role to play in determining whether an endophytic fungus acts as a symptomless endophyte or otherwise as a symptom-producing plant pathogen (Saikkonen et al., 1998; Schulz and Boyle, 2005; Hyde and Soytong, 2008; Porras-Alfaro and Bayman, 2011).

On the basis of the host plant part that is affected by the fungal endophytes, they can be classified as root and foliar endophytes. The possibility of endophytic fungi to exhibit preferential tissue colonization within their colonized hosts has widely been reported. For instance, in a study conducted by Behie et al. (2015), B. bassiana and Pochonia chlamydosporia were reportedly localized within the stems and leaves, while Metarhizium spp. was mostly found within the plant roots. Several other previous findings have also reported the potential of endophytic fungi exhibiting localized endophytic colonization rather than colonizing the host plants systemically (Impullitti and Malvick, 2013; Yan et al., 2015). Thus, fungal endophytes that infect plant roots (as in the case of Fusarium spp., Metarhizium spp., Piriformospora indica, and Glomus spp.) are known as root endophytes (Varma et al., 1999; Wilberforce et al., 2003; Wyrebek et al., 2011). These groups of endophytes infect plant tissues from the rhizosphere (Skipp and Christensen, 1989). Other endophytes that invade stems and leaves of plants or species that are primarily localized to the foliar part of the plant are known as foliar endophytes (Meyling et al., 2011).

Fungal endophytes are generally identified based on their morphological features, they can be isolated from their host plant tissues and cultured in the most suitable growth media for morphological identification and classification (Clark et al., 1983). However, aside morphological characterization, there 
are suggestions that, isolation and molecular characterization of entomopathogenic endophytes are very imperative in order to expand the current data on entomopathogenic fungi ( $\mathrm{Lu}$ et al., 2015). Molecular phylogenetic classification to identify endophytes can be carried out through amplifying and sequencing a small fragment of fungi DNA (Chen et al., 2015). This practice involves the analysis of nucleic acids and proteins to study the evolutionary relationships of fungal endophytes. A molecular phylogenetic relationship of Epichloë typhina with other clavicipitaceous endophytes also confirms the suggestion that fungal endophytes may coevolve with their host plants (Schardl et al., 1991).

\section{HOST PLANTS ASSOCIATION WITH FUNGAL ENDOPHYTES OUTCOMES}

Fungal endophytes have been confirmed to produce several beneficial effects to their host plants (Arnold et al., 2003; Rodriguez et al., 2009). The potential of entomopathogenic fungal endophytes exerting detrimental effects on the insect pests feeding on the plants colonized by these endophytic pathogens has been widely reported in several recent studies (Quesada-Moraga et al., 2009; Gurulingappa et al., 2011; Gange et al., 2012; Gathage et al., 2016; Resquín-Romero et al., 2016; Sánchez-Rodríguez et al., 2018). Most of these findings provided results that indicate that plants colonized by endophytes are protected from substantial damage, and plant pests feeding on such plants are less productive. The mechanism through which endophytic fungi reduce insect herbivore damage are numerous, some of the common measures include: reduction in the insect developmental rate (Akello and Sikora, 2012; Akutse et al., 2013), causing feeding deterrence (McGee, 2002; Vega, 2008), retardation of insect growth, reducing survival and oviposition (Lacey and Neven, 2006; Martinuz et al., 2012).

Reduction in plant damage caused by many insect pests has been reported in several crop plants following treatment with endophytic entomopathogenic fungi. For instance, reduction in poppy stem gall wasp (Iraella luteipes) (Hymenoptera: Cynipidae) damage in opium poppy treated with $B$. bassiana was found by Quesada-Moraga et al. (2009), reduced tunneling by lepidopteran larvae of European corn borer Ostrinia nubilalis Hübner (Lepidoptera: Pyralidae) and Sesamia calamistis Hampson (Lepidoptera; Noctuidae) was also reported in maize (Bing and Lewis, 1991; Lewis et al., 2001; Cherry et al., 2004). See also (Bing and Lewis, 1992; Wagner and Lewis, 2000).

Leckie (2002) reported a reduction in the damage caused by Helicoverpa zea (Lepidoptera; Noctuidae) in tomato following treatment with B. bassiana (see also Powell et al., 2009). H. zea was also reported to be controlled in cotton using $B$. bassiana and Purpureocillium lilacinum (Lopez and Sword, 2015). 50\% mortality of all larval instars and reduced longevity of Tuta absoluta (Meyrick) (Lepidoptera: Gelechiidae) larvae fed with B. bassiana colonized tomato leaves was also recorded by Klieber and Reineke (2016). Qayyum et al. (2015) also found a reduction in Helicoverpa armigera damage of tomato plants.
Posada et al. (2007) recorded a similar result with Coffee berry borer (Hypothenemus hampei) in coffee plant treated with B. bassiana. Akello et al. (2008a) found a similar reduction in larval survival and overall reduction in plant damage by banana weevil (Cosmopolites sordidus) (Coleoptera: Curculionidae). See also (Akello et al., 2008b).

Reduction in damage caused by the cotton aphid Aphis gossypii Glover (Hemiptera: Aphididae) and white jute stem weevil (Apion corchori) in cotton and white jute respectively was reported by Gurulingappa et al. (2010) and Biswas et al. (2013). In addition, in our previous study, we also found a similar reduction in damage caused by Liriomyza huidobrensis (Diptera: Agromyzidae) in Vicia faba and P. vulgaris (see Akutse et al., 2013). Some other reports on insect pests damage reduction following treatment of crops with entomopathogenic fungi are available (see Kim et al., 2008, 2010; Muvea et al., 2014; ResquínRomero et al., 2016; Jaber and Araj, 2017; Rondot and Reineke, 2018; Sánchez-Rodríguez et al., 2018). Most of these studies have attributed the reduction in the damage by insect pests to the accumulation of mycotoxins in plant tissues (Gurulingappa et al., 2011). Clay and Schardl (2002) opined that the harmful effects of endophytic fungi on insect herbivores are due to the production of fungal metabolites.

Some previous studies have also indicated the possibility of using fungal endophytes and natural enemies such as parasitoids in combination for suppressing insect herbivore population and damage in plant. For instance, Jaber and Araj (2017) reported the possibility of using endophytic fungal entomopathogens, B. bassiana and Metarhizium brunneum in combination with the aphid endoparasitoid Aphidius colemani Viereck (Hymenoptera: Braconidae) for the management of the green peach aphid Myzus persicae Sulzer (Homoptera: Aphididae) in sweet pepper Capsicum annum L. (Solanaceae). Similarly, in one of our previous studies, we also reported the possibility of utilizing endophytic entomopathogenic fungi and either of the two leafminer parasitoids Phaedrotoma scabriventris (Hymenoptera: Braconidae) and Diglyphus isaea (Hymenoptera: Eulophidae) in combination for the management of pea leafminer L. huidobrensis in V. faba (Akutse et al., 2014) (see also Barker and Addison, 1996, 1997; Bultman et al., 2003; De Sassi et al., 2006).

However, some of the previous studies reported negative effect of fungal endophytes on the natural enemies parasitizing insects feeding on fungi-colonized plants (Bultman et al., 1997; Omacini et al., 2001; Faeth and Bultman, 2002; Kunkel and Grewal, 2003; Kunkel et al., 2004). The negative effects reported include reductions in growth, fecundity and adult survival of natural enemies (Omacini et al., 2001). The primary cause of these adverse effects is the transmission of mycotoxins across the food chain from the colonized plants through the insect pests to the parasitoids. A typical example is the case of Neotyphodium coenophialum which produces loline alkaloids that reduced the survival of the parasitoid Euplectrus comstokii introduced in tall fescue for the management of fall armyworm (Spodoptera frugiperda) (Bultman et al., 1997). Kunkel et al. (2004) also suggested that the negative effects of endophytic fungi on natural enemies may 
be due to the transfer of endophyte-produced toxins. There are also suggestions that the reduction in the size of insect herbivores feeding on endophyte-infected plants (Richmond et al., 2004) and possible reduction in nutritional value of the insects due to infection by endophytic entomopathogenic fungi may indirectly affect the natural enemies (Omacini et al., 2001).

Aside herbivore management, the potential of endophytic entomopathogenic fungi serving dual purpose biological control of both insects and plant pathogens has been reported (Ownley et al., 2004, 2008a; Griffin et al., 2006; Kim et al., 2007, 2010; Vega, 2008; Vega et al., 2009; Jaber and Salem, 2014; Jaber, 2015). Ownley et al. (2008b) reported that endophytic colonization of tomato and cotton seedlings through seed soaking in B. bassiana conidia protected the seedlings against plant pathogenic Rhizoctonia solani and Pythium myriotylum. In another study by Flori and Roberti (1993), basal rot of onion (a disease caused by Fusarium oxysporum f. sp. cepae) was significantly reduced following treatment of onion bulbs with B. bassiana. Similarly, disease incidence and severity of downy mildew - caused by Plasmopara viticola (Berk. and Curt.) Berl. and de Toni. was also significantly reduced in grapevine following colonization of leave tissues by B. bassiana (Jaber, 2015). The evidence of $B$. bassiana offering protection against plant viral pathogens is also available. Jaber and Salem (2014) found evidence of reduction in disease incidence and severity of Zucchini yellow mosaic virus (ZYMV) in B. bassiana inoculated squash plants.

In addition to pests and diseases management, fungi occurring in the host plants as endophytes provide other benefits to the colonized host. Established beneficial effects include: increasing plant growth (Lopez and Sword, 2015; Jaber and Enkerli, 2016), plant development and nutrients (nitrogen and phosphorus) uptake into plants (Behie et al., 2012; Behie and Bidochka, 2014) and improvement in overall plant hardiness (Khan et al., 2012), as well as, preventing colonization of the host by foreign parasitic organisms (Martinuz et al., 2012).

Endophytes colonize the host plant tissue hence creating a barrier that prevents foreign pathogenic organisms from colonizing the same host plant and consequently control phytopathogenic diseases (Moy et al., 2000). Endophytes are considered as primary sources of bioactive compounds, that not only serve as storehouse of unique bioactive secondary metabolites, such as alkaloids, saponins, tannins, phenolic acids, steroids, quinones and terpenoids, but also act as insect antagonist, antimicrobial, anticancer and many other important properties (Gouda et al., 2016). They can as well be referred to as biofertilizers because they serve as plant growth promoters that facilitate nutrient uptake not only through plant root system, but also through the transfer of the insect-derived nitrogen to plants. For example, Metarhizium robertsii infects and kills soil-born insects, produces fungal mycelia from the dead insects and thereafter, forms an endophytic association with the plant roots, hence enhancing nitrogen translocation (Behie et al., 2012). The findings from the study conducted by Behie and Bidochka (2014) indicated that each of the crop plants examined - haricot bean ( $P$. vulgaris), wheat
(T. aestivum), soybean (G. max), and switchgrass (Panicum virgatum), derived a substantial amount of nitrogen from the soil insects infected with entomopathogenic fungi. They opined that $M$. robertsii possibly supplied nitrogen to the crop plants in exchange for carbon. There is evidence that nitrogen uptake by plants in this plant-fungi-soil interaction may play a larger role in soil nitrogen cycling and insect pests' infection.

Fungal endophytes also improve the colonized plant height, weight and other growth parameters are also influenced. Jaber and Enkerli (2017) reported an improvement in the height, fresh weight of shoots and roots of $V$. faba plants following artificial inoculation of Beauveria brongniartii, B. bassiana and M. brunneum. In another study, B. bassiana and P. lilacinum also increased the growth and dry biomass of colonized cotton plants (Lopez and Sword, 2015). Several other previous studies have also related improved plant growth with endophytic entomopathogenic fungi. See (Kabaluk and Ericsson, 2007; Elena et al., 2011; Sasan and Bidochka, 2012; Liao et al., 2014; Jaber and Enkerli, 2016; Jaber and Araj, 2017).

Endophytes also induce chemicals that impede the growth and development of other competitors, including pathogenic organisms (Clark et al., 1989), help plants not only to tolerate biotic stresses such as below-ground herbivory by nematodes and other root-feeding insects (Cosme et al., 2016), but also, abiotic stresses, including salt, drought or heat stresses (Khan et al., 2012). Endophytic fungi also indirectly enhance seed dispersal by ants. In a study by Knoch et al. (1993), seeds of Fescue (Festuca arundinacea L. Schreb) infected with Acremonium coenophialum (now known as Neotyphodium coenophialum) were protected against two primary seed harvesting ants Pogonomyrmex rugosus and Pogonomyrmex occidentalis. The infected seeds were discarded after being collected by the ants and this periodic dispersal by the insects indirectly improves seed distribution.

However, not all endophytic fungi-plant associations protect plants from insect herbivores, only few species associations act as defense mutualisms. In some cases, the presence of fungal endophytes in a plant can result in higher rates of water loss in leaves and it has been recorded that some endomycorrhizae may increase pest damage by making their host plants more susceptible to the pest (Mueller et al., 2005).

The beneficial effects of fungal endophytes on the host plants and primary pests are numerous and not limited to those highlighted so far in this review. The suggestion that the subject cannot be discussed exhaustively cannot be far from the truth. Our opinion is, there might be other roles of fungal endophytes yet uncovered. However, it is of note that, few reports on certain harmful effects on the host plants are also available (see Table 1 and Supplementary Figure S1). In the light of this, it is of note that, the relationship that exists between host plants and endophytes can be likened to a balanced antagonism, as the host derives both positive and negative effects depending on the environmental conditions (Saikkonen et al., 1998; Schulz et al., 1999). Hence, the environmental conditions could be said to distinguish a mutualistic endophyte from a pathogenic endophyte (Richardson, 2000; Schulz and Boyle, 2005). 
TABLE 1 | Effects of fungal endophytes on their colonized host plants and the primary pests.

\section{S/N Fungal endophyte effects}

$1 \quad$ Fungal endophytes induce systemic resistance in the colonized plants. They could also be transferred vertically from parent plants to their offspring, hence providing same resistance for the next generation.

2 Fungal endophytes protect host plants against plant pathogens. This has been reported in B. bassiana and Lecanicillium longisporum.

$3 \quad$ Fungal endophytes have also been found to induce a reduction in insects feeding on endophytic colonized plants.

$4 \quad$ Endophytic fungi alter the nutritional level of the colonized plant and utilize this in the production of secondary metabolites. Certain chemical defenses previously reported to have been mediated by the plant have recently been proven to be induced by endophytic fungi.

$5 \quad$ Fungal endophytes improve tolerance of colonized plants to biotic stress such as root herbivory by plant parasitic nematodes.

$6 \quad$ Fungal endophytes assist the colonized host plants in providing protection against insect herbivores. They cause retardation of insect growth, developmental rate and adult survival rate.

7 After successful colonization of the plant, certain fungal endophytes prevent colonization of the same plant by other foreign parasitic organisms. They produce chemicals that inhibit the growth of other pathogenic organisms and competitors.

8 Fungal endophytes cause deterrence, the potentials of repelling insects from feeding on colonized plants has been ascribed to fungal endophytes. The mechanism for deterrence has been linked to the changes in the chemical composition of the endophytically colonized plants.

$9 \quad$ Fungi promote nutrients uptake in their colonized plants. The increase in phosphorus and nitrogen uptake has been reported

10 They improve the plant's tolerance to abiotic stresses, such as salt, drought or heat stresses. Improvement in overall plant hardiness has also been reported as endophytic fungi effects.

11 Fungal endophytes improve crop yield, plant growth, cell division and development. Improvement in crop yield and fresh weight of common bean and corn plants treated with $M$. anisopliae, $B$. bassiana and $H$. lixii has been reported. Also, B. bassiana and $M$. brunneum improved several growth parameters in sweet pepper (C. annum) and V. faba.

12 Oviposition rate is reduced; fungal endophytes make plant herbivores sterile and less productive, through changes in the chemical composition or profiles of the host plants that deter oviposition of adult insects.

13 Fungal endophytes also serve as reservoirs of novel bioactive compounds. They produce metabolites, antibiotics, bioactive volatile compounds (such as ammonia, lipids, alkyl pyrones, hydrogen cyanide, alcohols, ketones and esters).

14 Endophytic fungi indirectly enhance seed dispersal by ants

15 Aside from insects' deterrence, there are also reports of fungal endophytes ability to deter vertebrate herbivores such as birds, rabbits and deer from feeding on fungal colonized plants.

16 Fungal endophytes (in the case of mycorrhizae) distribute nutrients within the surrounding plants and other mycorrhizae.

Some detrimental effects on host plants and natural enemies

17 Fungal endophytes build up the host defense system at the detriment of the reproductive potential. Certain fungal endophytes were found to render grasses partially sterile at the expense of their fungal reproductive structures.

18 In some cases, fungal endophytes when occurring in plant might increase transpiration rate in the leaves.

19 Some endo-mycorrhizae may increase herbivore damage in plants by making their host plants more susceptible to the insect pests.

20 Fungal endophytes may indirectly protect insect pests against their natural enemies, by producing alkaloids such as ergovaline, loline, etc. that reduce the developmental rate and survival of natural enemies. Certain endophytic fungi-induced toxins mediate reduced susceptibility of insects to their natural enemies such as parasitoids and entomopathogenic nematodes.

\section{Reference}

Saikkonen et al., 2002; Griffin et al., 2006; Ownley et al., 2008b

Kim et al., 2007, 2008, 2010; Ownley et al., 2008b; Jaber and Salem, 2014; Jaber, 2015; Puri et al., 2016

Knoch et al., 1993

Rowan et al., 1986

Sikora et al., 2007, 2008; Cosme et al., 2016

Saikkonen et al., 2004; Arnold and Lewis, 2005; Lacey and Neven, 2006; Jallow et al., 2008; Kim et al., 2008, 2010; Muvea et al., 2014; Resquín-Romero et al., 2016; Jaber and Araj, 2017;

Rondot and Reineke, 2018; Sánchez-Rodríguez et al., 2018

Moy et al., 2000; Martinuz et al., 2012

Latch et al., 1985; Tanada and Kaya, 1993; Daisy et al., 2002; McGee, 2002

Behie et al., 2012; Behie and Bidochka, 2014

Márquez et al., 2007; Hamilton and Bauerle, 2012; Junker et al., 2012; Khan et al., 2012

Kabaluk and Ericsson, 2007; Elena et al., 2011; Behie et al., 2012; Sasan and Bidochka, 2012; Behie and Bidochka, 2014; Liao et al., 2014; Lopez and Sword, 2015; Gathage et al., 2016; Jaber and Enkerli, 2016; Jaber and Araj, 2017; Jaber and Enkerli, 2017

Schmidt and Osborn, 1993

Clark et al., 1989; Bills et al., 1992; Calhoun et al., 1992; White et al., 2003; Schardl et al., 2013

Knoch et al., 1993

Lekberg and Koide, 2005

Franklin et al., 2014

Clay et al., 1989

White et al., 1993

Mueller et al., 2005

Bultman et al., 1997; Omacini et al., 2001; Kunkel and Grewal, 2003; Kunkel et al., 2004 


\section{CONCLUSION}

Fungal endophytes provide protection for crop plants against insects attack. The ability to minimize attack from all kinds of insect pests; lepidopterous larvae, aphids and thrips, and other cosmopolitan insects has widely been reported. This has also been the primary aim of artificial inoculation of entomopathogenic fungi into economic crops to establish as endophytes.

Aside insect management, the potential of fungal endophytes in providing protection for plants against plant-parasitic nematodes and plant disease pathogens, enhancing host growth, promoting nutrient acquisition and improving tolerance to abiotic stresses, as well as enhancing resistance to mammalian herbivores have all been reported and clearly emphasized in this review.

Since fungal endophytes promote phosphorus, nitrogen and other essential nutrients uptake in the host plants, deep knowledge on this would assist organic and inorganic fertilizer users to ensure optimum usage. Moreover, the ability of fungal endophytes to improve the plant ability to tolerate heat stress, salt, drought and other abiotic stresses adds a new dimension to host plants-endophytes interactions, and could significantly be explored or used in agriculture not only to mitigate pests and diseases under climate change conditions, but also as an alternative approach to entomopathogenic fungi autodissemination in inundating application. That is, fungal endophytes could be a suitable replacement for entomopathogenic fungi which are normally applied as inundative sprays to offer short-term pest control. These entomopathogenic fungi when successfully established as endophytes in plants can offer long-term pests and diseases control.

\section{REFERENCES}

Agrios, G. N. (1988). Plant Pathology, 3rd Edn. New York, NY: Academic Press, 845 .

Akello, J. (2012). Biodiversity of Fungal Endophytes Associated with Maize, Sorghum and Napier Grass and the Influence of Biopriming on Resistance to Leaf Mining, Stem Boring and Sap Sucking Insect Pests. Bonn: ZEF.

Akello, J., Dubois, T., Coyne, D., and Kyamanywa, S. (2008a). Effect of endophytic Beauveria bassiana on populations of the banana weevil, Cosmopolites sordidus, and their damage in tissue-cultured banana plants. Entomol. Exp. Appl. 129, 157-165. doi: 10.1111/j.1570-7458.2008.00759.x

Akello, J., Dubois, T., Coyne, D., and Kyamanywa, S. (2008b). Endophytic Beauveria bassiana in banana (Musa spp.) reduces banana weevil (Cosmopolites sordidus) fitness and damage. Crop Prot. 27, 1437-1441. doi: 10.1016/j.cropro. 2008.07.003

Akello, J., and Sikora, R. (2012). Systemic acropedal influence of endophyte seed treatment on Acyrthosiphon pisum and Aphis fabae offspring development and reproductive fitness. Biol. Control 61, 215-221. doi: 10.1016/j.biocontrol.2012. 02.007

Akutse, K., Maniania, N., Fiaboe, K., Van Den Berg, J., and Ekesi, S. (2013). Endophytic colonization of Vicia faba and Phaseolus vulgaris (Fabaceae) by fungal pathogens and their effects on the life-history parameters of Liriomyza huidobrensis (Diptera: Agromyzidae). Fungal Ecol. 6, 293-301. doi: 10.1016/j. funeco.2013.01.003

Akutse, K. S., Fiaboe, K. K., Van Den Berg, J., Ekesi, S., and Maniania, N. K. (2014). Effects of endophyte colonization of Vicia faba (Fabaceae) plants on the life-history of leafminer parasitoids Phaedrotoma scabriventris (Hymenoptera:
The recent discoveries indicating that fungal endophytes provide other beneficial effects to their host plants aside mere protection against pests will go a long way in defining the huge importance of fungal endophytes in crop production for human sustainability. Also, we hope that this information would increase the effective use of fungal endophytes by exploring all their functional attributes as an integral part of the integrated pest management programs throughout the different agroecological zones worldwide.

\section{AUTHOR CONTRIBUTIONS}

LW designed the review outline. The manuscript was written by $\mathrm{BB}, \mathrm{KA}$, and $\mathrm{CD}$. KA and RK reviewed the manuscript.

\section{ACKNOWLEDGMENTS}

We appreciate the Fujian Agriculture and Forestry University Scholarship Council for providing scholarships for postgraduate study.

\section{SUPPLEMENTARY MATERIAL}

The Supplementary Material for this article can be found online at: https://www.frontiersin.org/articles/10.3389/fmicb. 2018.00544/full\#supplementary-material

FIGURE S1 | Fungi, host plants and primary pests interactions.

Braconidae) and Diglyphus isaea (Hymenoptera: Eulophidae). PLoS One 9:e109965. doi: 10.1371/journal.pone.0109965

Alvarez-Loayza, P., White, J. F. Jr., Torres, M. S., Balslev, H., Kristiansen, T., Svenning, J.-C., et al. (2011). Light converts endosymbiotic fungus to pathogen, influencing seedling survival and niche-space filling of a common tropical tree, Iriartea deltoidea. PLoS One 6:e16386. doi: 10.1371/journal.pone.001 6386

Arnold, A. E., and Lewis, L. C. (2005). "Ecology and evolution of fungal endophytes and their roles against insects," in Insect-Fungal Associations: Ecology and Evolution, eds F. E. Vega and M. Blackwell (New York, NY: Oxford University Press), 74-96.

Arnold, A. E., and Lutzoni, F. (2007). Diversity and host range of foliar fungal endophytes: are tropical leaves biodiversity hotspots? Ecology 88, 541-549.

Arnold, A. E., Mejía, L. C., Kyllo, D., Rojas, E. I., Maynard, Z., Robbins, N., et al. (2003). Fungal endophytes limit pathogen damage in a tropical tree. Proc. Natl. Acad. Sci. U.S.A. 100, 15649-15654. doi: 10.1073/pnas.25334 83100

Azevedo, J. L., Maccheroni, W. Jr., Pereira, J. O., and De Araújo, W. L. (2000). Endophytic microorganisms: a review on insect control and recent advances on tropical plants. Electron. J. Biotechnol. 3, 15-16. doi: 10.2225/vol3-issue1fulltext-4

Barker, G. M., and Addison, P. J. (1996). Influence of clavicipitaceous endophyte infection in ryegrass on development of the parasitoid Microctonus hyperodae loan (Hymenoptera: Braconidae) in Listronotus bonariensis (Kuschel) (Coleoptera: Curculionidae). Biol. Control 7, 281-287. doi: 10.1006/bcon.1996.0095 
Barker, G. M., and Addison, P. J. (1997). Clavicipitaceous endophytic infection in ryegrass influences attack rate of the parasitoid Microctonus hyperodae (Hymenoptera: Braconidae, Euphorinae) in Listronotus bonariensis (Coleoptera: Curculionidae). Environ. Entomol. 26, 416-420. doi: 10.1093/ee/ 26.2.416

Behie, S., Zelisko, P., and Bidochka, M. (2012). Endophytic insect-parasitic fungi translocate nitrogen directly from insects to plants. Science 336, 1576-1577. doi: 10.1126/science. 1222289

Behie, S. W., and Bidochka, M. J. (2014). Ubiquity of insect-derived nitrogen transfer to plants by endophytic insect-pathogenic fungi: an additional branch of the soil nitrogen cycle. Appl. Environ. Microbiol. 80, 1553-1560. doi: 10.1128/ AEM.03338-13

Behie, S. W., Jones, S. J., and Bidochka, M. J. (2015). Plant tissue localization of the endophytic insect pathogenic fungi Metarhizium and Beauveria. Fungal Ecol. 13, 112-119. doi: 10.1128/AEM.03338-13

Bennett, R., Hutmacher, R., Davis, R., and Bennett, R. (2008). Seed transmission of Fusarium oxysporum f. sp. vasinfectum race 4 in California. J. Cotton Sci. 12, $160-164$.

Bills, G. F., Giacobbe, R. A., Lee, S. H., Peláez, F., and Tkacz, J. S. (1992). Tremorgenic mycotoxins, paspalitrem A and C, from a tropical Phomopsis. Mycol. Res. 96, 977-983. doi: 10.1016/S0953-7562(09)80601-1

Bills, G. F., and Polishook, J. D. (1991). Microfungi from Carpinus caroliniana. Can. J. Bot. 69, 1477-1482. doi: 10.1139/b91-191

Bing, L. A., and Lewis, L. C. (1991). Suppression of Ostrinia nubilalis (Hübner) (Lepidoptera: Pyralidae) by endophytic Beauveria bassiana (Balsamo) Vuillemin. Environ. Entomol. 20, 1207-1211. doi: 10.1093/ee/20.4.1207

Bing, L. A., and Lewis, L. C. (1992). Endophytic Beauveria bassiana (Balsamo) Vuillemin in corn: the influence of the plant growth stage and Ostrinia nubilalis (Hübner). Biocontrol Sci. Technol. 2, 39-47. doi: 10.1080/0958315920935 5216

Bing, L. A., and Lewis, L. C. (1993). Occurrence of the entomopathogen Beauveria bassiana (Balsamo) Vuillemin in different tillage regimes and in Zea mays L. and virulence towards Ostrinia nubilalis (Hübner). Agric. Ecosyst. Environ. 45, 147-156. doi: 10.1016/0167-8809(93)90065-W

Biswas, C., Dey, P., Satpathy, S., Satya, P., and Mahapatra, B. (2013). Endophytic colonization of white jute (Corchorus capsularis) plants by different Beauveria bassiana strains for managing stem weevil (Apion corchori). Phytoparasitica 41, 17-21. doi: 10.1007/s12600-012-0257-x

Breen, J. (1994). Acremonium endophyte interactions with enhanced plant resistance to insects. Annu. Rev. Entomol. 39, 401-423. doi: 10.1146/annurev. en.39.010194.002153

Brem, D., and Leuchtmann, A. (2001). Epichloë grass endophytes increase herbivore resistance in the woodland grass Brachypodium sylvaticum. Oecologia 126, 522-530. doi: 10.1007/s004420000551

Brownbridge, M., Reay, S. D., Nelson, T. L., and Glare, T. R. (2012). Persistence of Beauveria bassiana (Ascomycota: Hypocreales) as an endophyte following inoculation of radiata pine seed and seedlings. Biol. Control 61, 194-200. doi: 10.1016/j.biocontrol.2012.01.002

Bultman, T. L., Borowicz, K. L., Schneble, R. M., Coudron, T. A., and Bush, L. P. (1997). Effect of a fungal endophyte on the growth and survival of two Euplectrus parasitoids. Oikos 78, 170-176. doi: 10.2307/3545812

Bultman, T. L., Mcneill, M., and Goldson, S. (2003). Isolate-dependent impacts of fungal endophytes in a multitrophic interaction. Oikos 102, 491-496. doi: $10.1034 / j .1600-0706.2003 .11477 . x$

Calhoun, L. A., Findlay, J. A., Miller, J. D., and Whitney, N. J. (1992). Metabolites toxic to spruce budworm from balsam fir needle endophytes. Mycol. Res. 96, 281-286. doi: 10.1016/S0953-7562(09)80939-8

Carroll, G. (1991). "Fungal associates of woody plants as insect antagonists in leaves and stems," in Microbial Mediation of Plant-Herbivore Interactions, eds P. Bar-bosa, V. A. Krischick, and C. G. Jones (New York, NY: Wiley), 253-271.

Carroll, G. (1995). Forest endophytes: pattern and process. Can. J. Bot. 73, 1316-1324. doi: 10.1139/b95-393

Chen, L., Li, X., Li, C., Swoboda, G. A., Young, C. A., Sugawara, K., et al. (2015). Two distinct Epichloë species symbiotic with Achnatherum inebrians, drunken horse grass. Mycologia 107, 863-873. doi: 10.3852/15-019

Cherry, A., Lomer, C., Djegui, D., and Schulthess, F. (1999). Pathogen incidence and their potential as microbial control agents in IPM of maize stem borers in West Africa. Biocontrol 44, 301-327. doi: 10.1023/A:1009991724251
Cherry, A. J., Banito, A., Djegui, D., and Lomer, C. (2004). Suppression of the stem-borer Sesamia calamistis (Lepidoptera; Noctuidae) in maize following seed dressing, topical application and stem injection with African isolates of Beauveria bassiana. Int. J. Pest Manag. 50, 67-73. doi: 10.1080/ 09670870310001637426

Clark, C. L., Miller, J. D., and Whitney, N. J. (1989). Toxicity of conifer needle endophytes to spruce budworm. Mycol. Res. 93, 508-512. doi: 10.1016/j. phytochem.2010.01.015

Clark, E., White, J., and Patterson, R. (1983). Improved histochemical techniques for the detection of Acremonium coenophialum in tall fescue and methods of in vitro culture of the fungus. J. Microbiol. Methods 1, 149-155. doi: 10.1016/ 0167-7012(83)90033-7

Clay, K. (1989). Clavicipitaceous endophytes of grasses: their potential as biocontrol agents. Mycol. Res. 92, 1-12. doi: 10.1016/S0953-7562(89)80088-7

Clay, K., Cheplick, G. P., and Marks, S. (1989). Impact of the fungus Balansia henningsiana on Panicum agrostoides: frequency of infection, plant growth and reproduction, and resistance to pests. Oecologia 80, 374-380. doi: 10.1007/ BF00379039

Clay, K., and Schardl, C. (2002). Evolutionary origins and ecological consequences of endophyte symbiosis with grasses. Am. Nat. 160, S99-S127. doi: 10.1086/ 342161

Cosme, M., Lu, J., Erb, M., Stout, M. J., Franken, P., and Wurst, S. (2016). A fungal endophyte helps plants to tolerate root herbivory through changes in gibberellin and jasmonate signaling. New Phytol. 211, 1065-1076. doi: 10.1111/nph.13957

Daisy, B. H., Strobel, G. A., Castillo, U., Ezra, D., Sears, J., Weaver, D. K., et al. (2002). Naphthalene, an insect repellent, is produced by Muscodor vitigenus, a novel endophytic fungus. Microbiology 148, 3737-3741. doi: 10.1099/00221287148-11-3737

De Sassi, C., Müller, C. B., and Krauss, J. (2006). Fungal plant endosymbionts alter life history and reproductive success of aphid predators. Proc. Biol. Sci. 273, 1301-1306. doi: 10.1098/rspb.2005.3442

Delaye, L., García-Guzmán, G., and Heil, M. (2013). Endophytes versus biotrophic and necrotrophic pathogens-are fungal lifestyles evolutionarily stable traits? Fungal Divers. 60, 125-135. doi: 10.1007/s13225-013-0240-y

Dongyi, H., and Kelemu, S. (2004). Acremonium implicatum, a seed-transmitted endophytic fungus in Brachiaria grasses. Plant Dis. 88, 1252-1254. doi: 10.1016/ j.mycres.2007.10.008

Elena, G. J., Beatriz, P. J., Alejandro, P., and Lecuona, R. (2011). Metarhizium anisopliae (Metschnikoff) Sorokin promotes growth and has endophytic activity in tomato plants. Adv. Biol. Res. 5, 22-27.

Elmi, A., West, C., Robbins, R., and Kirkpatrick, T. (2000). Endophyte effects on reproduction of a root-knot nematode (Meloidogyne marylandi) and osmotic adjustment in tall fescue. Grass Forage Sci. 55, 166-172. doi: 10.1046/j.13652494.2000.00210.x

Faeth, S. H., and Bultman, T. L. (2002). "Endophytic fungi and interactions among host plants, herbivores, and natural enemies," in Multitrophic Level Interactions, eds T. Tscharntke and B. A. Hawkins (Cambridge: Cambridge University Press), 89-123.

Faeth, S. H., and Fagan, W. F. (2002). Fungal endophytes: common host plant symbionts but uncommon mutualists. Integr. Comp. Biol. 42, 360-368. doi: $10.1093 / \mathrm{icb} / 42.2 .360$

Flori, P., and Roberti, R. (1993). Treatment of onion bulbs with antagonistic fungi for the control of Fusarium oxysporum f. sp. cepae. Difesa delle Piante 16, 5-12.

Franklin, O., Näsholm, T., Högberg, P., and Högberg, M. N. (2014). Forests trapped in nitrogen limitation-an ecological market perspective on ectomycorrhizal symbiosis. New Phytol. 203, 657-666. doi: 10.1111/nph.12840

Fürnkranz, M., Lukesch, B., Müller, H., Huss, H., Grube, M., and Berg, G. (2012). Microbial diversity inside pumpkins: microhabitat-specific communities display a high antagonistic potential against phytopathogens. Microb. Ecol. 63, 418-428. doi: 10.1007/s00248-011-9942-4

Fuller-Schaefer, C., Jung, K., and Jaronski, S. (2005). "Colonization of sugarbeet roots by entomopathogenic fungi," in Proceedings of the 38th Annual Meeting of the Society for Invertebrate Pathology, Anchorage, AK.

Gange, A. C., Eschen, R., Wearn, J. A., Thawer, A., and Sutton, B. C. (2012). Differential effects of foliar endophytic fungi on insect herbivores attacking a herbaceous plant. Oecologia 168, 1023-1031. doi: 10.1007/s00442-011-2151-5

Gathage, J. W., Lagat, Z. O., Fiaboe, K. K. M., Akutse, K. S., Ekesi, S., and Maniania, N. K. (2016). Prospects of fungal endophytes in the control of Liriomyza 
leafminer flies in common bean Phaseolus vulgaris under field conditions. Biocontrol 61, 741-753. doi: 10.1007/s10526-016-9761-0

Gouda, S., Das, G., Sen, S. K., Shin, H.-S., and Patra, J. K. (2016). Endophytes: a treasure house of bioactive compounds of medicinal importance. Front. Microbiol. 7:1538. doi: 10.3389/fmicb.2016.01538

Greenfield, M., Gómez-Jiménez, M. I., Ortiz, V., Vega, F. E., Kramer, M., and Parsa, S. (2016). Beauveria bassiana and Metarhizium anisopliae endophytically colonize cassava roots following soil drench inoculation. Biol. Control 95, 40-48. doi: 10.1016/j.biocontrol.2016.01.002

Griffin, M., Ownley, B., Klingeman, W., and Pereira, R. (2006). Evidence of induced systemic resistance with Beauveria bassiana against Xanthomonas in cotton. Phytopathology 96:S42.

Gurulingappa, P., Mcgee, P. A., and Sword, G. (2011). Endophytic Lecanicillium lecanii and Beauveria bassiana reduce the survival and fecundity of Aphis gossypii following contact with conidia and secondary metabolites. Crop Prot. 30, 349-353. doi: 10.1016/j.cropro.2010.11.017

Gurulingappa, P., Sword, G. A., Murdoch, G., and Mcgee, P. A. (2010). Colonization of crop plants by fungal entomopathogens and their effects on two insect pests when in planta. Biol. Control 55, 34-41. doi: 10.1016/j.biocontrol. 2010.06.011

Hamilton, C. E., and Bauerle, T. L. (2012). A new currency for mutualism? Fungal endophytes alter antioxidant activity in hosts responding to drought. Fungal Divers. 54, 39-49.

Hardoim, P. R., Van Overbeek, L. S., Berg, G., Pirttilä, A. M., Compant, S., Campisano, A., et al. (2015). The hidden world within plants: ecological and evolutionary considerations for defining functioning of microbial endophytes. Microbiol. Mol. Biol. Rev. 79, 293-320. doi: 10.1128/MMBR.00050-14

Hartley, S. E., and Gange, A. C. (2009). Impacts of plant symbiotic fungi on insect herbivores: mutualism in a multitrophic context. Annu. Rev. Entomol. 54, 323-342. doi: 10.1146/annurev.ento.54.110807.090614

Hawksworth, D. L. (2001). The magnitude of fungal diversity: the 1.5 million species estimate revisited. Mycol. Res. 105, 1422-1432. doi: 10.1017/ S0953756201004725

Higgins, K. L., Arnold, A. E., Miadlikowska, J., Sarvate, S. D., and Lutzoni, F. (2007). Phylogenetic relationships, host affinity, and geographic structure of boreal and arctic endophytes from three major plant lineages. Mol. Phylogenet. Evol. 42, 543-555. doi: 10.1016/j.ympev.2006.07.012

Hyde, K., and Soytong, K. (2008). The fungal endophyte dilemma. Fungal Divers. $33,163-173$.

Impullitti, A., and Malvick, D. (2013). Fungal endophyte diversity in soybean. J. Appl. Microbiol. 114, 1500-1506. doi: 10.1111/jam.12164

Jaber, L. R. (2015). Grapevine leaf tissue colonization by the fungal entomopathogen Beauveria bassiana s.l. and its effect against downy mildew. Biocontrol 60, 103-112. doi: 10.1007/s10526-014-9618-3

Jaber, L. R., and Araj, S.-E. (2017). Interactions among endophytic fungal entomopathogens (Ascomycota: Hypocreales), the green peach aphid Myzus persicae Sulzer (Homoptera: Aphididae), and the aphid endoparasitoid Aphidius colemani Viereck (Hymenoptera: Braconidae). Biol. Control 116, 53-61. doi: 10.1016/j.biocontrol.2017.04.005

Jaber, L. R., and Enkerli, J. (2016). Effect of seed treatment duration on growth and colonization of Vicia faba by endophytic Beauveria bassiana and Metarhizium brunneum. Biol. Control 103, 187-195. doi: 10.1016/j.biocontrol.2016.09.008

Jaber, L. R., and Enkerli, J. (2017). Fungal entomopathogens as endophytes: can they promote plant growth? Biocontrol Sci. Technol. 27, 28-41. doi: 10.1080/ 09583157.2016.1243227

Jaber, L. R., and Salem, N. M. (2014). Endophytic colonisation of squash by the fungal entomopathogen Beauveria bassiana (Ascomycota: Hypocreales) for managing Zucchini yellow mosaic virus in cucurbits. Biocontrol Sci. Technol. 24, 1096-1109. doi: 10.1080/09583157.2014.923379

Jallow, M. F., Dugassa-Gobena, D., and Vidal, S. (2008). Influence of an endophytic fungus on host plant selection by a polyphagous moth via volatile spectrum changes. Arthropod Plant Interact. 2, 53-62. doi: 10.1007/s11829-008-9033-8

Junker, C., Draeger, S., and Schulz, B. (2012). A fine line - endophytes or pathogens in Arabidopsis thaliana. Fungal Ecol. 5, 657-662. doi: 10.1016/j.funeco.2012. 05.002

Kabaluk, J. T., and Ericsson, J. D. (2007). Seed treatment increases yield of field corn when applied for wireworm control. Agron. J. 99, 1377-1381. doi: 10.2134/ agronj2007.0017N
Kandalepas, D., Blum, M. J., and Van Bael, S. A. (2015). Shifts in symbiotic endophyte communities of a foundational salt marsh grass following oil exposure from the Deepwater Horizon oil spill. PLoS One 10:e0122378. doi: 10.1371/journal.pone. 0122378

Kemen, E., and Jones, J. D. (2012). Obligate biotroph parasitism: can we link genomes to lifestyles? Trends Plant Sci. 17, 448-457. doi: 10.1016/j.tplants.2012. 04.005

Khan, A. L., Hamayun, M., Khan, S. A., Kang, S.-M., Shinwari, Z. K., Kamran, M., et al. (2012). Pure culture of Metarhizium anisopliae LHL07 reprograms soybean to higher growth and mitigates salt stress. World J. Microbiol. Biotechnol. 28, 1483-1494. doi: 10.1007/s11274-011-0950-9

Kim, J. J., Goettel, M. S., and Gillespie, D. R. (2007). Potential of Lecanicillium species for dual microbial control of aphids and the cucumber powdery mildew fungus, Sphaerotheca fuliginea. Biol. Control 40, 327-332. doi: 10.1016/ j.biocontrol.2006.12.002

Kim, J. J., Goettel, M. S., and Gillespie, D. R. (2008). Evaluation of Lecanicillium longisporum, Vertalec ${ }^{\circledR}$ for simultaneous suppression of cotton aphid, Aphis gossypii, and cucumber powdery mildew, Sphaerotheca fuliginea, on potted cucumbers. Biol. Control 45, 404-409. doi: 10.1016/j.biocontrol.2008.02.003

Kim, J. J., Goettel, M. S., and Gillespie, D. R. (2010). Evaluation of Lecanicillium longisporum, Vertalec ${ }^{\circledR}$ against the cotton aphid, Aphis gossypii, and cucumber powdery mildew, Sphaerotheca fuliginea in a greenhouse environment. Crop Prot. 29, 540-544. doi: 10.1016/j.cropro.2009.12.011

Klieber, J., and Reineke, A. (2016). The entomopathogen Beauveria bassiana has epiphytic and endophytic activity against the tomato leaf miner Tuta absoluta. J. Appl. Entomol. 140, 580-589. doi: 10.1111/jen.12287

Knoch, T. R., Faeth, S. H., and Arnott, D. L. (1993). Endophytic fungi alter foraging and dispersal by desert seed-harvesting ants. Oecologia 95, 470-473. doi: 10.1007/BF00317429

Kunkel, B. A., and Grewal, P. S. (2003). Endophyte infection in perennial ryegrass reduces the susceptibility of black cutworm to an entomopathogenic nematode. Entomol. Exp. Appl. 107, 95-104. doi: 10.1046/j.1570-7458.2003.00048.x

Kunkel, B. A., Grewal, P. S., and Quigley, M. (2004). A mechanism of acquired resistance against an entomopathogenic nematode by Agrotis ipsilon feeding on perennial ryegrass harboring a fungal endophyte. Biol. Control 29, 100-108. doi: 10.1016/S1049-9644(03)00119-1

Lacey, L. A., and Neven, L. G. (2006). The potential of the fungus, Muscodor albus, as a microbial control agent of potato tuber moth (Lepidoptera: Gelechiidae) in stored potatoes. J. Invertebr. Pathol. 91, 195-198. doi: 10.1016/j.jip.2006.01.002

Latch, G., Christensen, M., and Gaynor, D. (1985). Aphid detection of endophyte infection in tall fescue. N. Z. J. Agric. Res. 28, 129-132. doi: 10.1080/00288233. 1985.10427006

Leckie, B. M. (2002). Effects of Beauveria bassiana Mycelia and Metabolites Incorporated into Synthetic Diet and Fed to Larval Helicoverpa zea; and Detection of Endophytic Beauveria bassiana in Tomato Plants Using PCR and ITS Primers. Master thesis, University of Tennessee, Knoxville, TN.

Lekberg, Y., and Koide, R. (2005). Is plant performance limited by abundance of arbuscular mycorrhizal fungi? A meta-analysis of studies published between 1988 and 2003. New Phytol. 168, 189-204. doi: 10.1111/j.1469-8137.2005. 01490.x

Leuchtmann, A., Schmidt, D., and Bush, L. (2000). Different levels of protective alkaloids in grasses with stroma-forming and seed-transmitted Epichloë/Neotyphodium endophytes. J. Chem. Ecol. 26, 1025-1036. doi: 10.1023/A:1005489032025

Lewis, L. C., Bruck, D. J., Gunnarson, R. D., and Bidne, K. G. (2001). Assessment of plant pathogenicity of endophytic Beauveria bassiana in Bt transgenic and nontransgenic corn. Crop Sci. 41, 1395-1400. doi: 10.2135/cropsci2001.4151395x

Liao, X., O'brien, T. R., Fang, W., and Leger, R. J. S. (2014). The plant beneficial effects of Metarhizium species correlate with their association with roots. Appl. Microbiol. Biotechnol. 98, 7089-7096. doi: 10.1007/s00253-014-5788-2

Lopez, D. C., and Sword, G. A. (2015). The endophytic fungal entomopathogens Beauveria bassiana and Purpureocillium lilacinum enhance the growth of cultivated cotton (Gossypium hirsutum) and negatively affect survival of the cotton bollworm (Helicoverpa zea). Biol. Control 89, 53-60. doi: 10.1016/j. biocontrol.2015.03.010

Lopez, D. C., Zhu-Salzman, K., Ek-Ramos, M. J., and Sword, G. A. (2014). The entomopathogenic fungal endophytes Purpureocillium lilacinum (formerly Paecilomyces lilacinus) and Beauveria bassiana negatively affect cotton aphid 
reproduction under both greenhouse and field conditions. PLoS One 9:e103891. doi: 10.1371/journal.pone.0103891

Lu, L., Cheng, B., Du, D., Hu, X., Peng, A., Pu, Z., et al. (2015). Morphological, molecular and virulence characterization of three Lencanicillium species infecting Asian citrus psyllids in Huangyan citrus groves. J. Invertebr. Pathol. 125, 45-55. doi: 10.1016/j.jip.2015.01.002

Márquez, L. M., Redman, R. S., Rodriguez, R. J., and Roossinck, M. J. (2007). A virus in a fungus in a plant: three-way symbiosis required for thermal tolerance. Science 315, 513-515. doi: 10.1126/science.1136237

Martinuz, A., Schouten, A., and Sikora, R. (2012). Systemically induced resistance and microbial competitive exclusion: implications on biological control. Phytopathology 102, 260-266. doi: 10.1094/PHYTO-04-11-0120

McGee, P. (2002). Reduced growth and deterrence from feeding of the insect pest Helicoverpa armigera associated with fungal endophytes from cotton. Aust. J. Exp. Agric. 42, 995-999. doi: 10.1071/EA01124

Meyling, N. V., Thorup-Kristensen, K., and Eilenberg, J. (2011). Below-and aboveground abundance and distribution of fungal entomopathogens in experimental conventional and organic cropping systems. Biol. Control 59, 180-186. doi: 10.1016/j.biocontrol.2011.07.017

Moon, C. D., Tapper, B. A., and Scott, B. (1999). Identification of Epichloë endophytes in planta by a microsatellite-based PCR fingerprinting assay with automated analysis. Appl. Environ. Microbiol. 65, 1268-1279.

Moy, M., Belanger, F., Duncan, R., Freehoff, A., Leary, C., Meyer, W., et al. (2000). Identification of epiphyllous mycelial nets on leaves of grasses infected by clavicipitaceous endophytes. Symbiosis 28, 291-302.

Mueller, R. C., Sthultz, C. M., Martinez, T., Gehring, C. A., and Whitham, T. G. (2005). The relationship between stem-galling wasps and mycorrhizal colonization of Quercus turbinella. Botany 83, 1349-1353. doi: 10.1139/b05-105

Muvea, A. M., Meyhöfer, R., Subramanian, S., Poehling, H.-M., Ekesi, S., and Maniania, N. K. (2014). Colonization of onions by endophytic fungi and their impacts on the biology of Thrips tabaci. PLoS One 9:e108242. doi: 10.1371/ journal.pone.0108242

Niere, B. I. (2001). Significance of Non-pathogenic Isolates of Fusarium oxysporum Schlecht: Fries for the Biological Control of the Burrowing Nematode Radopholus similis (Cobb) Thorne on Tissue Cultured Banana. Ph.D. thesis, University of Bonn, Bonn.

Omacini, M., Chaneton, E. J., Ghersa, C. M., and Müller, C. B. (2001). Symbiotic fungal endophytes control insect host-parasite interaction webs. Nature 409, 78-81. doi: 10.1038/35051070

Orole, O., and Adejumo, T. (2009). Activity of fungal endophytes against four maize wilt pathogens. Afr. J. Microbiol. Res. 3, 969-973.

Ownley, B. H., Dee, M. M., and Gwinn, K. (2008a). Effect of conidial seed treatment rate of entomopathogenic Beauveria bassiana 11-98 on endophytic colonization of tomato seedlings and control of Rhizoctonia disease. Phytopathology 98:S118.

Ownley, B. H., Griffin, M. R., Klingeman, W. E., Gwinn, K. D., Moulton, J. K., and Pereira, R. M. (2008b). Beauveria bassiana: endophytic colonization and plant disease control. J. Invertebr. Pathol. 98, 267-270. doi: 10.1016/j.jip.2008.01.010

Ownley, B. H., Pereira, R. M., Klingeman, W. E., Quigley, N. B., and Leckie, B. M. (2004). "Beauveria bassiana, a dual purpose biological control with activity against insect pests and plant pathogens," in Emerging Concepts in Plant Health Management 2004, eds R. T. Lartey and A. J. Caesar (Trivandrum: Research Signpost), 255-269.

Pace, N. R. (1997). A molecular view of microbial diversity and the biosphere. Science 276, 734-740. doi: 10.1126/science.276.5313.734

Parsa, S., Ortiz, V., Gómez-Jiménez, M. I., Kramer, M., and Vega, F. E. (2016). Root environment is a key determinant of fungal entomopathogen endophytism following seed treatment in the common bean, Phaseolus vulgaris. Biol. Control 116, 74-81. doi: 10.1016/j.biocontrol.2016.09.001

Parsa, S., Ortiz, V., and Vega, F. E. (2013). Establishing fungal entomopathogens as endophytes: towards endophytic biological control. J. Vis. Exp. 74:50360. doi: $10.3791 / 50360$

Petrini, O. (1991). "Fungal endophytes of tree leaves," in Microbial Ecology of Leaves, eds J. H. Andrews and S. S. Hirano (New York, NY: Springer), 179-197. doi: 10.1007/978-1-4612-3168-4_9

Pimentel, I. C., Glienke-Blanco, C., Gabardo, J., Stuart, R. M., and Azevedo, J. L. (2006). Identification and colonization of endophytic fungi from soybean (Glycine max (L.) Merril) under different environmental conditions. Braz. Arch. Biol. Technol. 49, 705-711. doi: 10.1590/S1516-89132006000600003
Pinto, L. S. R. C., Azevedo, J. L., Pereira, J. O., Vieira, M. L. C., and Labate, C. A. (2000). Symptomless infection of banana and maize by endophytic fungi impairs photosynthetic efficiency. New Phytol. 147, 609-615. doi: 10.1046/j. 1469-8137.2000.00722.x

Porras-Alfaro, A., and Bayman, P. (2011). Hidden fungi, emergent properties: endophytes and microbiomes. Annu. Rev. Phytopathol. 49, 291-315. doi: 10.1146/annurev-phyto-080508-081831

Posada, F., Aime, M. C., Peterson, S. W., Rehner, S. A., and Vega, F. E. (2007). Inoculation of coffee plants with the fungal entomopathogen Beauveria bassiana (Ascomycota: Hypocreales). Mycol. Res. 111, 748-757. doi: 10.1016/j. mycres.2007.03.006

Powell, W. A., Klingeman, W. E., Ownley, B. H., and Gwinn, K. D. (2009). Evidence of endophytic Beauveria bassiana in seed-treated tomato plants acting as a systemic entomopathogen to larval Helicoverpa zea (Lepidoptera: Noctuidae). J. Entomol. Sci. 44, 391-396. doi: 10.18474/0749-8004-44.4.391

Promputtha, I., Lumyong, S., Dhanasekaran, V., Mckenzie, E. H. C., Hyde, K. D., and Jeewon, R. (2007). A phylogenetic evaluation of whether endophytes become saprotrophs at host senescence. Microb. Ecol. 53, 579-590. doi: 10.1007/ s00248-006-9117-x

Purahong, W., and Hyde, K. D. (2011). Effects of fungal endophytes on grass and non-grass litter decomposition rates. Fungal Divers. 47, 1-7. doi: 10.1007/ s13225-010-0083-8

Puri, A., Padda, K. P., and Chanway, C. P. (2016). Evidence of nitrogen fixation and growth promotion in canola (Brassica napus L.) by an endophytic diazotroph Paenibacillus polymyxa P2b-2R. Biol. Fertil. Soils 52, 119-125. doi: 10.1007/ s00374-015-1051-y

Qayyum, M. A., Wakil, W., Arif, M. J., Sahi, S. T., and Dunlap, C. A. (2015). Infection of Helicoverpa armigera by endophytic Beauveria bassiana colonizing tomato plants. Biol. Control 90, 200-207. doi: 10.1016/j.biocontrol.2015.04.005

Quesada-Moraga, E., Landa, B., Muñoz-Ledesma, J., Jiménez-Diáz, R., and Santiago-Alvarez, C. (2006). Endophytic colonisation of opium poppy, Papaver somniferum, by an entomopathogenic Beauveria bassiana strain Mycopathologia 161, 323-329. doi: 10.1007/s11046-006-0014-0

Quesada-Moraga, E., López-Díaz, C., and Landa, B. B. (2014). The hidden habit of the entomopathogenic fungus Beauveria bassiana: first demonstration of vertical plant transmission. PLoS One 9:e89278. doi: 10.1371/journal.pone. 0089278

Quesada-Moraga, E., Munoz-Ledesma, F., and Santiago-Alvarez, C. (2009). Systemic protection of Papaver somniferum L. against Iraella luteipes (Hymenoptera: Cynipidae) by an endophytic strain of Beauveria bassiana (Ascomycota: Hypocreales). Environ. Entomol. 38, 723-730. doi: 10.1603/022. 038.0324

Reddy, N. P., Khan, A. P. A., Devi, U. K., Sharma, H. C., and Reineke, A. (2009). Treatment of millet crop plant (Sorghum bicolor) with the entomopathogenic fungus (Beauveria bassiana) to combat infestation by the stem borer, Chilo partellus Swinhoe (Lepidoptera: Pyralidae). J. Asia Pac. Entomol. 12, 221-226. doi: 10.1016/j.aspen.2009.06.001

Resquín-Romero, G., Garrido-Jurado, I., Delso, C., Ríos-Moreno, A., and QuesadaMoraga, E. (2016). Transient endophytic colonizations of plants improve the outcome of foliar applications of mycoinsecticides against chewing insects. J. Invertebr. Pathol. 136, 23-31. doi: 10.1016/j.jip.2016.03.003

Richardson, M. D. (2000). "Alkaloids of endophyte-infected grasses: defence chemicals or biological anomalies," in Microbial Endophytes, eds C. W. Bacon and J. F. White Jr. (New York, NY: Marcel Dekker), 323-340.

Richmond, D. S., Grewal, P. S., and Cardina, J. (2004). Influence of Japanese beetle Popillia japonica larvae and fungal endophytes on competition between turfgrasses and dandelion. Crop Sci. 44, 600-606. doi: 10.2135/cropsci2004.6000

Rodriguez, R., White, J. Jr., Arnold, A., and Redman, R. (2009). Fungal endophytes: diversity and functional roles. New Phytol. 182, 314-330. doi: 10.1111/j.14698137.2009.02773.x

Rondot, Y., and Reineke, A. (2018). Endophytic Beauveria bassiana in grapevine Vitis vinifera (L.) reduces infestation with piercing-sucking insects. Biol. Control. 116, 82-89. doi: 10.1016/j.biocontrol.2016.10.006

Rowan, D. D., Hunt, M. B., and Gaynor, D. L. (1986). Peramine, a novel insect feeding deterrent from ryegrass infected with the endophyte Acremonium loliae. J. Chem. Soc. Chem. Commun. 935-936. doi: 10.1039/c39860000935

Russo, M. L., Pelizza, S. A., Cabello, M. N., Stenglein, S. A., and Scorsetti, A. C. (2015). Endophytic colonisation of tobacco, corn, wheat and soybeans by 
the fungal entomopathogen Beauveria bassiana (Ascomycota, Hypocreales). Biocontrol Sci. Technol. 25, 475-480. doi: 10.1080/09583157.2014.982511

Sánchez-Rodríguez, A. R., Raya-Díaz, S., Zamarreño, Á. M., García-Mina, J. M., Del Campillo, M. C., and Quesada-Moraga, E. (2018). An endophytic Beauveria bassiana strain increases spike production in bread and durum wheat plants and effectively controls cotton leafworm (Spodoptera littoralis) larvae. Biol. Control. 116, 90-102. doi: 10.1016/j.biocontrol.2017.01.012

Saikkonen, K., Faeth, S. H., Helander, M., and Sullivan, T. (1998). Fungal endophytes: a continuum of interactions with host plants. Annu. Rev. Ecol. Syst. 29, 319-343. doi: 10.1146/annurev.ecolsys.29.1.319

Saikkonen, K., Ion, D., and Gyllenberg, M. (2002). The persistence of vertically transmitted fungi in grass metapopulations. Proc. Biol. Sci. 269, 1397-1403. doi: $10.1098 / \mathrm{rspb} .2002 .2006$

Saikkonen, K., Lehtonen, P., Helander, M., Koricheva, J., and Faeth, S. H. (2006). Model systems in ecology: dissecting the endophyte-grass literature. Trends Plant Sci. 11, 428-433. doi: 10.1016/j.tplants.2006.07.001

Saikkonen, K., Wäli, P., Helander, M., and Faeth, S. H. (2004). Evolution of endophyte-plant symbioses. Trends Plant Sci. 9, 275-280. doi: 10.1016/j.tplants. 2004.04.005

Sasan, R. K., and Bidochka, M. J. (2012). The insect-pathogenic fungus Metarhizium robertsii (Clavicipitaceae) is also an endophyte that stimulates plant root development. Am. J. Bot. 99, 101-107. doi: 10.3732/ajb.1100136

Schardl, C., and Craven, K. (2003). Interspecific hybridization in plant-associated fungi and oomycetes: a review. Mol. Ecol. 12, 2861-2873. doi: 10.1046/j.1365294X.2003.01965.x

Schardl, C. L., Liu, J.-S., White, J. F., Finkel, R. A., An, Z., and Siegel, M. R. (1991). Molecular phylogenetic relationships of nonpathogenic grass mycosymbionts and clavicipitaceous plant pathogens. Plant Syst. Evol. 178, 27-41. doi: 10.1007/ BF00937980

Schardl, C. L., Young, C. A., Pan, J., Florea, S., Takach, J. E., Panaccione, D. G., et al. (2013). Currencies of mutualisms: sources of alkaloid genes in vertically transmitted epichloae. Toxins 5, 1064-1088. doi: 10.3390/toxins5061064

Schmidt, S., and Osborn, T. (1993). Effects of endophyte-infected tall fescue on animal performance. Agric. Ecosyst. Environ. 44, 233-262. doi: 10.1016/01678809(93)90049-U

Schulz, B., and Boyle, C. (2005). The endophytic continuum. Mycol. Res. 109, 661-686. doi: 10.1017/S095375620500273X

Schulz, B., Römmert, A.-K., Dammann, U., Aust, H.-J., and Strack, D. (1999). The endophyte-host interaction: a balanced antagonism? Mycol. Res. 103, 1275-1283. doi: 10.1017/S0953756299008540

Sieber, T. N. (2007). Endophytic fungi in forest trees: are they mutualists? Fungal Biol. Rev. 21, 75-89. doi: 10.1016/j.fbr.2007.05.004

Sikora, R., Schäfer, K., and Dababat, A. (2007). Modes of action associated with microbially induced in planta suppression of plant-parasitic nematodes. Australas. Plant Pathol. 36, 124-134. doi: 10.1071/AP07008

Sikora, R. A., Pocasangre, L., Zum Felde, A., Niere, B., Vu, T. T., and Dababat, A. (2008). Mutualistic endophytic fungi and in-planta suppressiveness to plant parasitic nematodes. Biol. Control 46, 15-23. doi: 10.1016/j.biocontrol.2008.02.011

Skipp, R., and Christensen, M. (1989). Host specificity of root-invading fungi from New Zealand pasture soils. Australas. Plant Pathol. 18, 101-103. doi: 10.1071/ APP9890101
Suryanarayanan, T. S. (2013). Endophyte research: going beyond isolation and metabolite documentation. Fungal Ecol. 6, 561-568. doi: 10.1016/j.funeco.2013. 09.007

Tanada, Y., and Kaya, H. (1993). Insect Pathology. San Diego, CA: Academic Press, 666.

Tefera, T., and Vidal, S. (2009). Effect of inoculation method and plant growth medium on endophytic colonization of sorghum by the entomopathogenic fungus Beauveria bassiana. Biocontrol 54, 663-669. doi: 10.1007/s10526-0099216-y

Varma, A., Verma, S., Sahay, N., Bütehorn, B., and Franken, P. (1999). Piriformospora indica, a cultivable plant-growth-promoting root endophyte. Appl. Environ. Microbiol. 65, 2741-2744.

Vega, F. E. (2008). Insect pathology and fungal endophytes. J. Invertebr. Pathol. 98, 277-279. doi: 10.1016/j.jip.2008.01.008

Vega, F. E., Goettel, M. S., Blackwell, M., Chandler, D., Jackson, M. A., Keller, S., et al. (2009). Fungal entomopathogens: new insights on their ecology. Fungal Ecol. 2, 149-159. doi: 10.1016/j.funeco.2009.05.001

Vega, F. E., Posada, F., Aime, M. C., Pava-Ripoll, M., Infante, F., and Rehner, S. A. (2008). Entomopathogenic fungal endophytes. Biol. Control 46, 72-82. doi: 10.1016/j.biocontrol.2008.01.008

Wagner, B. L., and Lewis, L. C. (2000). Colonization of corn, Zea mays, by the entomopathogenic fungus Beauveria bassiana. Appl. Environ. Microbiol. 66, 3468-3473. doi: 10.1128/AEM.66.8.3468-3473.2000

White, J. F. Jr., Bacon, C. W., Hywel-Jones, N. L., and Spatafora, J. W. (2003). Clavicipitalean Fungi: Evolutionary Biology, Chemistry, Biocontrol and Cultural Impacts. Boca Raton, FL: CRC Press. doi: 10.1201/9780203912706

White, J. F. Jr., Glenn, A. E., and Chandler, K. F. (1993). Endophyte-host associations in grasses. XVIII. Moisture relations and insect herbivory of the emergent stromal leaf of Epichloe. Mycologia 85, 195-202. doi: 10.2307/376 0456

Wilberforce, E., Boddy, L., Griffiths, R., and Griffith, G. (2003). Agricultural management affects communities of culturable root-endophytic fungi in temperate grasslands. Soil Biol. Biochem. 35, 1143-1154. doi: 10.1016/S00380717(03)00176-7

Wyrebek, M., Huber, C., Sasan, R. K., and Bidochka, M. J. (2011). Three sympatrically occurring species of Metarhizium show plant rhizosphere specificity. Microbiology 157, 2904-2911. doi: 10.1099/mic.0.051102-0

Yan, J., Broughton, S., Yang, S., and Gange, A. (2015). Do endophytic fungi grow through their hosts systemically? Fungal Ecol. 13, 53-59. doi: 10.1016/j.funeco. 2014.07.005

Conflict of Interest Statement: The authors declare that the research was conducted in the absence of any commercial or financial relationships that could be construed as a potential conflict of interest.

Copyright (c) 2018 Bamisile, Dash, Akutse, Keppanan and Wang. This is an openaccess article distributed under the terms of the Creative Commons Attribution License (CC BY). The use, distribution or reproduction in other forums is permitted, provided the original author(s) and the copyright owner are credited and that the original publication in this journal is cited, in accordance with accepted academic practice. No use, distribution or reproduction is permitted which does not comply with these terms. 